\title{
Examining the Mathematical Modeling Processes of Primary School 4th-Grade Students: Shopping Problem
}

\author{
Mustafa Ulu \\ Department of Education Sciences, Dumlupınar University, Turkey
}

Copyright $(2017$ by authors, all rights reserved. Authors agree that this article remains permanently open access under the terms of the Creative Commons Attribution License 4.0 International License

\begin{abstract}
The purpose of this study is to identify primary school students' thinking processes within the mathematical modeling process and the challenges they encounter, if any. This is a basic qualitative research study conducted in a primary school in the city of Kütahya in the academic year of 2015-2016. The study group of the research was composed of 22 students at 4th-grade who were selected with criterion sampling which is a purposive sampling method. The study data were collected with the clinical interview method and reported using the content analysis. It was consequently found that the students constituted two groups as those who provided a realistic solution and those who could not. There were more students who could not provide a realistic solution. Those who couldn't provide realistic solution tried to construct the mental representation of real situation through literal comprehension, which became insufficient in revealing the hidden situations involved in the problem text. Not noticing the hidden actions in the text led them to form a mathematical equation without structuring the problem and thus their solutions were unrealistic. Those who could provide realistic solutions, on the other hand, decide their operations within the context of the characters, time, place and relation between the events in the problem, which enabled the mental representation of the problem text to be critical reading and inferential comprehension focused as well as literal comprehension focused and thus allowed the students to reveal the hidden situations in the text. Accordingly, students posed new problems by gathering the required extra information according to these hidden situations and went for the real model. Thus, analyzing the problem situation is various contexts, students solved according to multiple conditions. It was also seen that students with realistic solutions utilized the validation process to determine the consistencies and inconsistencies of their solutions in real life context while those with unrealistic solutions utilized it to check their operations.
\end{abstract}

Keywords Primary School Students, Mathematical Modeling, Realistic Solution

\section{Introduction}

The PISA survey has become an influential factor in reforming educational practices (Liang, [93]) and making decisions about educational policy (Yore, Anderson, \& Hung Chiu, [95]). PISA results showed that the competencies measured in PISA surveys are better predictors for 15 year-old students' later success (Schleicher, [94]). One of the skills measured in PISA is mathematical literacy, which can be defined as "turning real-life problems into mathematics" and "interpreting existing knowledge and adapting it to real-life" (Blum and Niss, [13]; Lesh and Doerr, [50]). PISA categorizes problem solvers into seven levels. Those under the first level are the students who cannot solve problems, whereas the first level defines the students who can solve routine problems when the question is expressed clearly and all the required information is provided for solution. The second category defines the students who can reason simple relations that are evident at the first glance. The third level and above express the students who can adapt mathematics to real-life situations. PISA [95] revealed that $45.9 \%$ of the high school students trained in OECD countries are below the third level. These results show that approximately half of the high school students in OECD countries have trouble in solving real life problems. In Turkey, where the study was conducted, the situation is even more disturbing than the OECD countries because PISA [95] revealed that $77.6 \%$ of Turkish high school students cannot solve real world problems.

Studies by Verschaffel, Greer \&De Corte [81], Verschaffel, De Corte \&Vierstraete [80] Xin, Lin, Zhang \&Yan [87], and Çelik \& Güler [24] reveal that difficulties in solving real world problems start during primary school years. One of the problems used in these studies is "A school with 325 students wants to take its students on a picnic by buses with 50 seats each. How many buses are needed to take all the students on a picnic?" For solution, " $325 / 5=6.5$ " is not enough; a mathematical solution has no chance to occur in real life conditions. In this context, since the number of buses cannot be expressed as 0.5 , how 25 students will go on a picnic should be fictionalized. Suggestions for answers here 
might vary from one student to another like "Let's allocate the remaining students to the other buses" or "We can take a smaller minibus." It was seen in these studies that most of the students gave the answer " 6.5 buses are required." It was also seen in these studies that students couldn't come up with realistic solutions in similar problem situations.

With structural reforms in the mathematics curriculum in Singapore in 1992, the time spent on mathematical content where factual and operational skills are prominent was decreased $30 \%$ and problem solving skills were added at the same percentage (Kaur, [96]). Singapore mathematics curriculum gives as much importance to the time spent on problem solving activities as the problem types to be solved in the lesson. In this country, from the first years of primary school to the end of high school, the subject starts to be taught with exercise type problems and realistic problems follow when the subject has been understood (Kaur \& Yeap, [97]). When realistic problems were tackled in lessons, they were considered within the context of mathematical modeling. This was reflected to PISA results [98] and the rate of students below the third level in Singapore fell down to $\% 20.1$. The levels at which the highest mathematical skills are presented at PISA [98] are the fifth and sixth levels that determine students with mathematical modeling skills. According to PISA [98], the rate of students with mathematical modeling skills in Singapore is $34.8 \%$, while this rate falls down to $10.7 \%$ in OECD countries and to $1.1 \%$ in Turkey. The fact that students from Singapore have better performance in solving real world problems than their peers in other countries points out the need for developing mathematical modeling skills at early ages.

Schwarzkopt [71] states that interaction between real life and mathematics is needed for analyzing the content-based mathematical texts. Maass [57] defines this interaction as "mathematical modeling" and argues that the process of mathematical modeling starts with real-life problems and ends with results agreeing with real life. According to Lesh and Doerr [50], mathematical modeling is a process of transforming a qualitative real-life situation into a mathematical form and interpreting the acquired results again in real-life conditions by doing the necessary mathematical operations. Studies have shown that modeling activities provide students with: $(a)$ a powerful tool to use in developing critical and high-level thinking skills (English \& Watters, [30], (b) a new and effective learning environment where existing deficiencies in conceptual knowledge are identified and new mathematical knowledge is gained (Chamberlin, [21], (c) encouragement to use different and various representations to explain conceptual systems (Boaler, [15]; English\& Watters,[32]; Mousoulides,[54]).

Mathematical modeling studies have generally focused on high school and university students (Blum and Leiß, [12]; Borromeo Ferri \& Blum [18]; Wijaya et al., [89]; Hıdıroğlu, Dede, Kula \& Güzel, [37]. Verschaffel, Greer \&De Corte [81], Verschaffel, De Corte \& Vierstraete [80] Xin, Lin, Zhang \& Yan [87], and Çelik \& Güler [24] suggest that difficulties in modeling real-life problems start during primary school years. Therefore, English [31], Şahin [68], Şahin \& Eraslan [69] emphasized that students need to be introduced to modeling activities which involve real life situations so that they can be equipped with advanced mathematical skills as of primary school years. There are only the studies conducted by Şahin [68], Şahin \& Eraslan [69] which aimed at identifying primary school students' mathematical modeling skills in Turkey. In these studies, data were collected with the focus group interview method with 3 students chosen out of 18 students after a 5-week preliminary education provided for the primary school students and it was seen in the study that the primary school students tried daily life-related assumptions, produced opinions and tested the accuracy of their models by associating them with real life. In this context, a study has been needed to identify to what extent students can use the modeling cycle in regard only to their individual performances without a modeling education and group effect. Another reason why such a study was needed is that all necessary information for solving the problem was presented in the study conducted by Şahin and Eraslan [69]. However, because some real world problems may need the student to consider certain hidden actions to update the given problem, extra information may sometimes be required so that the actual problem can be modeled accurately. In this context, the purpose of this study is to identify primary $4^{\text {th }}$ grade students' thinking processes within the modeling process in real world problems requiring extra information and the challenges they encounter, if any.

\subsection{Theoretical framework}

According to Hegarty, Mayer \& Monk [35], there are two approaches in problem solving process: short-cut approach and comprehension- oriented. They stated that individuals decide their operations upon certain special words (more, less, times, etc.) they choose without understanding the problem in short-cut approach whereas in comprehension-oriented approach, they decide their operations within the context of the characters, time, place and relation between the events in the problem. In their studies, Hegarty et al. [35], Viennot and Moreau [82], Soylu and Soylu [73], Pape [62], Smith, Gerretson, Olkun \& Joutsenlahti [72] revealed that students with lower problem solving success do over-regularization whereas successful students achieve more real solutions by forming accurate relations between the problem elements (characters, time, place and events).

The short-cut approach assumes that solving different kinds of questions will enhance the problem-solving achievement as it will increase the number of solution methods stored in the memory. Yet, when the question is changed a little bit or students confront with a new question, this approach may fail to solve the problem (Viennot \&Moreau, [82] Jitendra \&Hoff, [40]; Steele \& Johanning,[75]. The readily available solutions mentioned in 
the short-cut approach are addressed within the scope of procedural knowledge (Anderson, [3]; Byrnes \& Wasik, [20], Baroody, Feil, \& Johnson, [8].

In a study by Soylu and Soylu [73], most of the students' answers to the question "When Ali gives 5 of his apples to Ayşe, he has 10 apples left, so how many apples did Ali have in the beginning?" was $10-5=5$. It was determined through an interview that as a result of over-regularizing the expression "left", students did subtraction instead of addition. In a study by Viennot and Moreau [82], students were first asked "Luke comes to school with 15 marbles. He plays two games and loses 7 marbles in the first game. At the end of the second game, Luke, being a good gamer, ends up with 34 marbles. How many marbles did Luke lose in the second game if he had lost or how many did he win if he had won the second game?" and then the same problem was asked again by replacing "a good gamer" with "a bad gamer". At the end of the study, it was determined that some of the students who wrote "He won 26 marbles" to the questions with "a good gamer" changed answer and said "He lost 26 marbles" to the questions with "a bad gamer". These two situations show that word-oriented solutions prevent achieving realistic solutions and so one should go for comprehension-oriented solutions.

The studies performed by Anderson, [3]; Brynes and Wasik [20]; and Baroody et al. [8], it was observed that the procedural knowledge may fall insufficient in the first-time situations and contextual knowledge is needed for such situations. Kieren [44] and Baroody et al. [8] defined conceptual knowledge as associating recently-learned knowledge with previously-learned knowledge and real life, constructing the knowledge in accordance with individual traits and processing it through a rational sieve. They emphasized that procedural knowledge may be enough for solving exercise type problems but process skills and conceptual knowledge are in the forefront as realistic problems have a more complex structure. According to NTCM [101] and MEB [54], today's educational programs advocate the idea "conceptual understanding rather than procedural knowledge or rule-driven computation" both mathematics-wise in general and problem solving-wise.

Emphasizing that there are similarities between understanding a story and a problem, Dijk \& Knitsch [79]; Kintsch \& Greeno [45] and Reusser [67], Staub and Reusser [74] stated that just as students should focus on the whole text to understand the story, so should they focus on the whole problem text instead of focusing on a single word to understand the problem accurately. Staub and Reusser [74] carried this idea one step further and structured a model called "from the text to situation and from situation to equation" that aims to help students solve a problem just as they analyze a story. This model was initially used to prevent elementary school students from over-regularizing while solving problems requiring addition and subtraction; however, it became the origin of modeling cycle- developed by Blum and Leiss [12] and finalized by Borromeo Ferri [16] aiming at solving realistic problems. The modeling cycle developed by Borromeo Ferri [16] is presented in Figure 1.

According to Figure 1, in the first phase, the mental representation of the situation model should be established in the real situation and it is expected from the solver to understand the problem. Contemporary approaches to story problem solving have emphasized the conceptual understanding of a story problem before attempting any solution that involves selecting and applying an arithmetic operation for solution (Jonassen, [41]. According to Kintsch [46] in conceptual understanding phase individual needs to comprehend the problem text literally, inferentially and critically. Literal comprehension, the first level of comprehension, requires that a student can extract information that is explicitly stated in a passage (Lapp \& Flood, [49]; McCormick, [53]. According to Kintsch ([46], literal comprehension lets us find answers for WH-questions (e.g. who, what, where, when, how) in the text. This level of understanding is dependent upon students' word-level processing skills, or their ability to accurately identify individual words and understand the meaning created by the combination of words into propositions and sentences (Perfetti, Landi, \& Oakhill, [65].

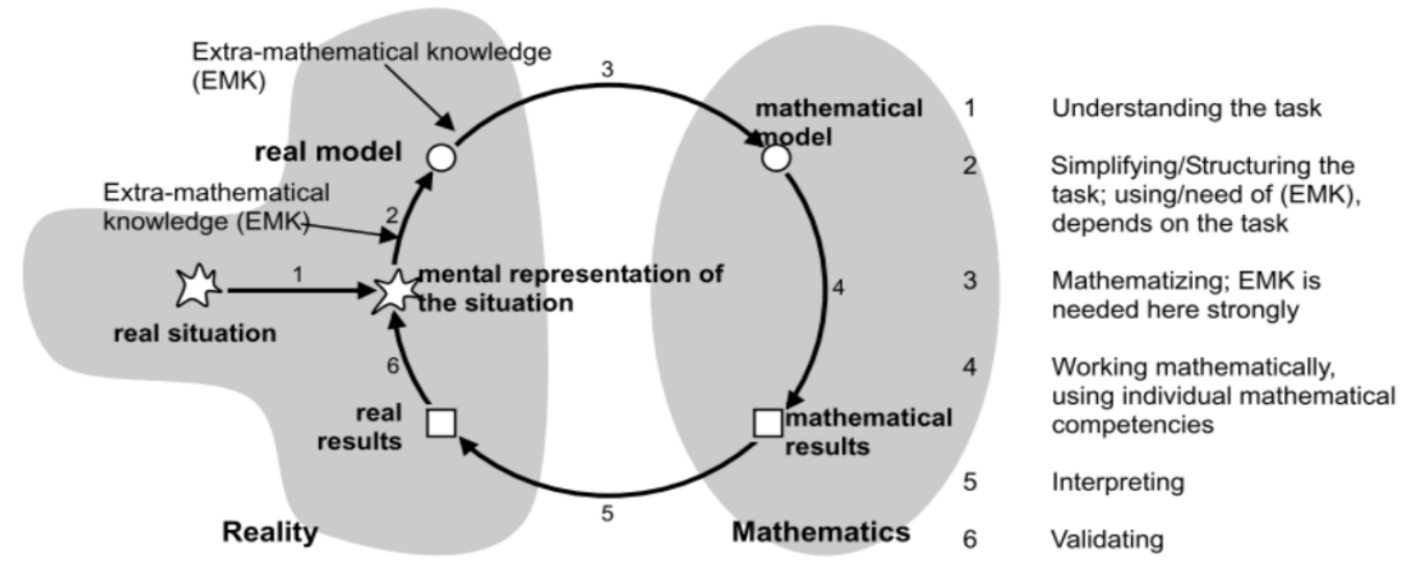

Figure 1. Modeling cycle from Borromeo Ferri [16] 
Inferential comprehension aims to establish empathy between the character in the text and the reader and to determine why the event in the text is being told, what its effects are on the reader, what the motives of the main character in the text are, what the main idea the author is trying to convey in the text is and the cause and effect relations between the events (Kneene \& Zimmermann, [43]. Kintsch [46] expresses inferential comprehension as a situational model and states that establishing a situational model during comprehension will activate the background information of the reader about the event and thus richer information units will be reached which are inclined to real life and whose connection with the background information has been established. It is stated that the main purpose in reading a text is thought to be inferential comprehension but literal comprehension is a prerequisite for inferential comprehension to occur (Allen, [1]; Kinsch, [46]; Suk, [76]; Vacca, Vacca, Gove, Burkey, Lenhart,\&McKeon, [77]; Ulu, [86].

Critical reading enables the individual to follow what words and sentences in the reading text mean and handle the text in a wider perspective. Within this framework, an individual who address the text from the critical point of view have the ability to survey the mind constantly and keep it alive (Odabaş, Odabaş \& Polat, [59]. During critical reading, the reader performs the act of reading by asking himself/herself questions about inconsistencies among thoughts or events handled in the text, the reasons why the text was written, and the appropriateness or sufficiency of examples given. It is necessary to utilize the abilities to investigate and analyze the causations of phenomena or events, produce thoughts, organize thoughts, compare opinions, make inferences, evaluate discussions and solve problems in this process (MEB, [54]. Individual, within this framework, is to comprehend the phenomena or events and the primary message to be given by them during critical reading in the first place (literal comprehension). Next, one needs to reveal the implicit meaning in the text. In this phase, individual tries to reveal the message that the author wants to communicate through causations (inferential comprehension) (Basaraba, Yovanoff, Alonzo, \& Tindal, [9]. After the causations have been revealed, individual relates between what he/she has read before, the experiences and information in his/her mind and the implicit information in text and makes an inference by judging, questioning, evaluating what he/she has obtained and benefiting from credible resources (Özensoy, [60]. Reader spends more time and effort in critical reading than in other reading techniques. While a non-critical reader accepts what is narrated in the text as being inarguably true and tries to memorize them, a critical reader is also interested in how the subject is described as much as paying attention to what is narrated and with what thoughts they are supported (Aşlıı̆lu, 2008).

Kispal [47], Chikalanga [23], Zwiers [92], Presley [66] and Kintsch [46] stated that an individual who made an inference and critical reading during comprehension was at the same time reasoning. The role of reasoning during problem solving was defined as reaching a solution by integrating every proposition in the problem text in a logical consistency (Leighton \&Sternberg, [48]. Regarding the definitions above, significant resemblances are seen between reading comprehension and reasoning skill during problem solving. Background information should be activated other information should be reached about the explicit information in the text both in inferential comprehension during reading comprehension and in reasoning during problem solving. Literature shows that a positive relation exists between problem solving and reasoning skills (Barbey \& Barsalou,[7]; Çelik \& Özdemir, [25]; Çetin \& Ertekin, [24]; Umay, [84]; Yurt \& Sünbül, [91]. Staub and Reusser [74] stated that the comprehension strategies can be utilized in this phase, and in the studies performed by Hite [36] and Ulu, Tertemiz \& Peker [85], it was seen that the problem-solving achievement can be improved just by giving training for comprehension strategies.

As seen in Figure 1, individuals who envision the problem situation and make sense of it are expected to simplify and structure the problem and those who have achieved this stage will have formed the real model. Reusser (1995), Niss, (2003), Borromeo Ferri (2007), Blum and Ferri (2009) define this stage the process of forming new problems by collecting the necessary new information according to hidden actions revealed in comprehension process. Simplifying is the discrimination of information necessary and unnecessary for solution. Structuring is the process of associating the problem elements based on the scenario in the problem text (Reusser, 1995; Niss, 2003). Borromeo Ferri (2005) thinks that the structuring step is a process of internal representation, in other words, taking the mental picture of the problem situation. Internal representation is composed of two steps: recall and association. Charles and Lester (1984), and Altun (2007) define individuals' asking themselves "Have I solved a similar problem before" as recall. Organizing the information from the long-term memory, discriminating what is given in the problem in accordance with what is asked and adapting it into the current problem situation are defined as association (Steele and Johanning, 2004; Cummins, Kintsch, Reusser and Weimer, 1988).

During the third stage, the solver is supposed to build the mathematical model with reference to the real model and in this process, the individual is supposed to do mathematization. Mathematization is a process in which a problem already existing in the brain structured non-graphically is converted into tables, figures or symbols (Blum and Borromeo Ferri, 2009; Borromeo Ferri, 2006). According to Niss (2003), at this stage, the strategy to be used for solution is operated and the next stagemathematical working- follows. In mathematical working process, figures, tables or equations are put into service to reach a mathematical solution.

According to Figure 1, the last phase of the process is coming back from the mathematical model to real model, and it is expected from the individual to interpret first and 
then validate. Blum [10] regards the interpreting phase as questioning the likelihood that the mathematical result occurs in real life. According to Borromeo Ferri \& Blum [19], Borromeo Ferri [16] the individual performs two types of validation: "intuitive validation" (more unconscious) and "knowledge-based validation (more conscious)." Intuitive validation is that the individual thinks he/she has made an error because of a situation he/she cannot explain; if he/she is to explain that error with mathematical evidence, he/she has performed a knowledge-based validation. In addition, Borromeo Ferri [17] regards the fact that individuals mistake the validation process for controlling the accuracy of the mathematical operations as a mistake and consider it rather individual's questioning if the solutions and the result obtained is reasonable in regard to real-life conditions. It was explored in the studies conducted by Maass [51], Wijaya, Panhuizen, Doorman \& Robitzsch [89], and Eraslan \& Kant [33] that the students gave up solving the problem generally in the mathematical result step and ignored two most important steps of the modeling cycle: interpretation and validation. The studies conducted by Teong [83], and Özsoy [61] found that using the control processes reduced the errors.

To see the processes of modeling cycle more concretely, a problem developed by Blum and Ferri (2009:46) to analyze the behaviors of high-school students in modeling process is presented in Figure 2.

Blum and Borromeo Ferri [14] explain the modeling process in the problem shown in Figure 2 as follows. The first step is to understand the given problem situation, that is the problem solver has to understand a situation model which here involves at least two gas stations and the $20 \mathrm{~km}$ connection. The second step is to structure the situation by bringing certain variables into play, especially tank volume and consumption rate of the Golf, and to simplify the situation by defining what "worthwhile" should mean, leading to a real model of the situation. In the standard model, "worthwhile" means only "minimising the costs of filling up and driving". Mathematisation, the third step, transforms the real model into a mathematical model which consists here of certain equations, perhaps with variables. The fourth step is working mathematically (calculating etc.) which yields mathematical results. In step five, these are interpreted in the real world as real results, ending up in a recommendation for Mrs. Stone of what to do. A validation of these results, step six, may show that it is appropriate or necessary to go round the loop a second time, for instance in order to take into account more factors such as time or air pollution. Dependent on which factors have been chosen, the recommendations for Mrs. Stone might be quite different. The seventh and final step is an exposure of the final solution. Several studies have shown that each step in the modelling process (see Fig. 1) is a potential cognitive barrier for students, a potential "blockage" or "red flag situation" (Galbraith \& Stillman [100]; Stillman [99]). " The studies performed by Blum \& Leiß [11], Borromeo Ferri \& Blum[18], Schapp, Vos \& Goedhart [70], Wischgoll, Pauli \& Reusser [88], and Wijaya et al. [89] also revealed that since students get stuck in understanding the situation and thus constructing a situation model, they could not evaluate all the variables together when transforming the real situation into the mathematical model. It has been seen that these troubles were caused by the fact that one cannot comprehend the elements given in various representative formats (verbal, visual, symbolic) in the model (English \&Watters, [32]; English, [31]; Şahin, [68]; Şahin \& Eraslan, [69], cannot transform what is given into different representative structures (English, [31]; Şahin [68]; Şahin \& Eraslan, [69] and cannot choose the right operation (English, [29]).

$$
\begin{aligned}
& \text { "Filling up" } \\
& \text { Mrs. Stone lives in Trier, } 20 \mathrm{~km} \text { away from the border of Luxemburg. } \\
& \text { To fill up her VW Golf she drives to Luxemburg where immediately } \\
& \text { behind the border there is a petrol station. There you have to pay } 1.10 \\
& \text { Euro for one litre of petrol whereas in Trier you have to pay } 1.35 \\
& \text { Euro. } \\
& \text { Is it worthwhile for Mrs. Stone to drive to Luxemburg? Give reasons } \\
& \text { for your answer. }
\end{aligned}
$$

Figure 2. The exemplary problem used within the scope of modeling studies (Blum and Borromeo Ferri [14]) 


\section{Method}

\subsection{Design of the Study}

According to Merriam [55], researchers do not always conduct a qualitative research study to examine a culture (ethnography), reveal a phenomenon (phenomenology), to create a theory, examine a given unit or a limited system (case study) or identify and solve a problem (action research). Researchers sometimes conduct qualitative research in an interpretative approach as in this study (Merriam, [55]; Merriam, [56]; Research that cannot be explained through other qualitative research designs and require an interpretive approach are considered within the scope of basic qualitative research design. In this study, too, it was aimed neither to study a culture or create a theory nor examine a given unit or limited system as in case studies. In accordance with the purpose of the study, the modeling processes and the difficulties confronted during the modeling process were addressed in an interpretative approach; the study was designed in accordance with the basic qualitative analysis approach in this context.

Piaget argues that errors made by children provide important information on their nature of thinking and it is necessary to use the clinical interview method, which is a method of asking flexible questions, to explore the richness of students' thoughts and evaluate the cognitive skill (Baki, Güven \& Karataş, [5]. According to Frederiksen, Glaser, Lesgold \& Shafto [34], standard tests can only determine to what extent the students solve the problem correctly or incorrectly but do not question why they do it correctly and what to do so that they achieve the right result. Karataş and Güven [42] regard the clinical interview method as one of the measurement methods that can be used for evaluating the problem-solving skill and think that the reason for the errors made by students when solving problems can be revealed as they are solving it. Hunting [39] stated that the clinical interview method is dynamic and the errors made by the student are identified rather by him/her. In this context, since students' thinking processes within the modeling process and the challenges they encounter, if any, are examined, clinical interview method was conducted

\subsection{Sampling}

The study group of the research was formed with the criterion sampling strategy which is a purposive sampling method; purposive sampling is the selection of data resources to provide rich information so that a case can be studied in depth (Yıldırım \& Şimşek, [90]. In this scope, five criteria that are directly related to the research purpose were set to select the sample which would provide the data. These criteria are: (1) students must be attending the 4 th grade of a primary school, (2) location of the school must be appropriate for the shopping problem used in the study, (3) the teacher have not solve a problem similar to the shopping problem in the in-class activities before, (4) the classroom teacher must believe that there are students in the class that can give different answers to the problem, and (5) the classroom teacher must be willing to participate in the study. According to these criteria, it was decided that the study group should be a Kütahya Dumlupınar College, training from Pre-school education to 8th grade, situated within the borders of the university central campus. The college was in the 4th place among 149 secondary schools in the 2014/2015 TEOG (Transition from Primary to Secondary Education) Exam ranking in Kütahya . There are three 4th-grade classes in this school; as a result of the interview made with the classroom teachers of these classes, one of them stated that the question was a high-level one and the students would find it difficult, another classroom did not take kindly to the application of the study in the classroom because he/she believed the research would take too long and impede the educational activities. The teacher of the third class stated that the class met the study criteria, he/she was not going to be able to continue teaching in the school for a personal problem and we could perform the application on the very same day. In accordance with teacher's opinions, it was decided that the study group was to be formed with the students of that class and the parents of those students were contacted with by the help of the school administration and necessary permissions were obtained. The study group was composed of 22 students (13 girls, 9 boys). Ages of the students vary between 10 years 2 months old and 10 years and 9 months old.

\subsection{Collection and Analysis of the Data}

In the study, the problem developed by Blum and Ferri [14] to examine the behaviors of high school students in mathematical modeling process was adopted as data gathering tool (see above: Fig 3). Since the original form of the question was prepared for the 8th-to-10th-grade (14-16 years old) students, it was adapted to the 4th-grade level (10 years old). In the adaptation process, three researchers who are specialized in the mathematics education in classroom teachers and five classroom teachers who were still teaching the 4 th grades were asked for support. The problem is given in Figure 3. 


The Shopping Problem:
Enes is studying in the 8th grade of Kütahva Dumlupmar College. He will
attend his Technology Design Class in the 6th and 7th class hours. The
teacher of the technology design class asked him and his friends last week
to bring cardboards in four different colors for today's class: orange,
yellow, green, and pink. Enes forgets to buy the cardboards.
A piece of cardboard is sold at 6 Turkish liras at the school canteen. His
friends tell him that they bought a piece at 3 Turkish liras at a stationary
next to the Vase.
Enes cannot decide whether to buy the cardboards from the school canteen
or the stationary next to the Vase during the lunch break.
Where would you suggest Enes to buy the cardboards from? Give reasons
for your answer.

Figure 3. Adapted version of the problem used for identifying 8th-to-10th-grade students' modeling skills by Blum and Borromeo Ferri [14] for the primary school 4 th-grade students

Table 1. Extra information that may be needed for the solution

\begin{tabular}{|c|c|}
\hline Questions & Answers \\
\hline How much is the carfare? & 1 lira 50 kuruş (discounted student carfare) \\
\hline How much is the taxi fare? & 50 liras for a round trip in total \\
\hline How long is the lunch break at the school? & 60 minutes \\
\hline $\begin{array}{l}\text { Is lunch served at the school? } \\
\text { If so, at what time? }\end{array}$ & There is lunch served for free at the school. Starts at 12.00 am and ends at $12.30 \mathrm{pm}$. \\
\hline $\begin{array}{l}\text { How long does it take for the busses to arrive at the } \\
\text { Vase? }\end{array}$ & $\begin{array}{l}\text { It takes } 20 \text { minutes for the busses to go to and } 20 \text { minutes to come back from the Vase } \\
\text { if there is no traffic jam. } \\
\text { It takes } 25 \text { minutes for the busses to go to and } 25 \text { minutes to come back from the Vase } \\
\text { in case of moderate traffic jam. } \\
\text { It takes } 30 \text { minutes for the busses to go to and } 30 \text { minutes to come back from the Vase } \\
\text { if there is heavy traffic. }\end{array}$ \\
\hline What is the time schedule for the busses? & $\begin{array}{l}\text { There is a bus from the school to the Vase in every } 3 \text { minutes. } \\
\text { There is a bus from the Vase to the school in every } 3 \text { minutes. }\end{array}$ \\
\hline How far is the stationery from the Vase? & 2 minutes at most. \\
\hline $\begin{array}{l}\text { Does Enes have the competence to get on the bus } \\
\text { and go to the Vase on his own? }\end{array}$ & $\begin{array}{l}\text { This question was asked to the 8th-grade students of the school and all of them said } \\
\text { they were able to get on the bus and go to the city center on their own and their families } \\
\text { were okay with that. }\end{array}$ \\
\hline
\end{tabular}

During the data collection processes, interviews were performed in a hall with two rooms so that interviewed students could not influence others who were not interviewed yet. One of the rooms is larger than the other. There are two doors in the larger part of the hall, one of which is used to go inside and get out and the other one for getting to the smaller part. In the smaller part, there is a door used to leave the hall other than the one that is used for getting to the larger part. In this context, all the 22 students which constituted the study group were taken into the larger part of the hall and they were summoned to the smaller part where the clinical interviews were performed in the order of their school numbers. The student whose interview was completed was sent to his/her classroom through the exit door in the smaller part. During the application, the students were asked for solving the problem and explaining the solution vocally. There was no time restriction for solving the problem. If the student needed the extra information given in Table 1 during the clinical interview, the information was shared with him/her.

The clinical interviews were videotaped and the content analysis was conducted on the videos to thematize them. The qualitative content analysis (Elo \& Kyngäs, [28]; Vaismoradi, Turunen \& Bondas, [78] technique was used to analyze the research data. Qualitative content analysis can be defined as the procedure of classifying and interpreting the content of written texts via encoding and creating themes or patterns systematically (Hsieh \& Shannon, [38]. So, the clinical interviews performed with 22 students on the shopping problem were first examined by three experts having $\mathrm{PhD}$ in mathematics education in problem solving, aging between 34 and 48. It was seen that seven different opinions were 
revealed as 3 liras, 12 liras, Carfare, Danger, Time, Lunch, and Taxi. The experts decided that these opinions were to constitute the research codes. Next, it was decided that the codes were to be examined in two themes according to the studies conducted by Verschaffel et al. [81], Verschaffel et al. [80], Xin et al. [87]: realistic and unrealistic solutions. Upon experts' unanimous decision, the solutions that only focused on the profit Enes would make without involving the commuting time into the solution since the distance from the school and the Vase is by no means walking distance were grouped as unrealistic while those questioning the cost, whether it would cause any problems in terms of time and whether it would be dangerous considering the Enes would have to take a vehicle to the Vase were grouped as realistic solutions. Finally, the themes and codes were evaluated in accordance with the modeling cycle stages developed by Blum \& Borromeo Ferri [14]. The opinions of an expert specialized in Turkish language was also received to evaluate individuals' reading skills.

\section{Findings}

In this section of the research, the content analysis was performed on video recordings of the clinical interviews which involve the answers to the shopping problem. The answers were encoded to conduct the content analysis and themes were created on the basis of the codes. The code and theme distribution of the participant students is given in Table 2 .

It is seen in Table 2 that the answers given by the participants are grouped in seven codes and two themes. Next sections of the study explain the themes and the codes related to the themes in a detailed manner.

Table 2. Codes created on the basis of the answers given to the shopping problem and the themes created by combining the codes

\begin{tabular}{|c|c|c|c|c|c|c|c|}
\hline Themes & $\begin{array}{l}\text { Unrealistic } \\
\text { Solutions }\end{array}$ & & $\begin{array}{l}\text { Realistic } \\
\text { Solutions }\end{array}$ & & & & \\
\hline Codes & 3 liras. & 12 liras. & Carfare & Danger & Time & Lunch & Taxi \\
\hline $\mathrm{S} 1$ & - & $\checkmark$ & - & - & - & - & - \\
\hline $\mathrm{S} 2$ & $\checkmark$ & - & - & - & - & - & - \\
\hline S3 & - & $\checkmark$ & $\checkmark$ & - & - & - & - \\
\hline $\mathrm{S} 4$ & - & - & $\checkmark$ & $\checkmark$ & $\checkmark$ & $\checkmark$ & $\checkmark$ \\
\hline S5 & - & $\checkmark$ & - & - & - & - & - \\
\hline S6 & - & $\checkmark$ & - & - & - & - & - \\
\hline S7 & $\checkmark$ & - & - & - & - & - & - \\
\hline S8 & - & $\checkmark$ & - & - & - & - & - \\
\hline S9 & - & - & $\checkmark$ & $\checkmark$ & $\checkmark$ & $\checkmark$ & - \\
\hline $\mathrm{S} 10$ & - & $\checkmark$ & $\checkmark$ & - & - & - & - \\
\hline $\mathrm{S} 11$ & $\checkmark$ & - & - & - & - & - & - \\
\hline $\mathrm{S} 12$ & - & - & $\checkmark$ & - & $\checkmark$ & - & - \\
\hline $\mathrm{S} 13$ & - & $\checkmark$ & - & - & - & - & - \\
\hline $\mathrm{S} 14$ & - & $\checkmark$ & $\checkmark$ & - & - & - & - \\
\hline S15 & - & $\checkmark$ & - & - & - & - & - \\
\hline $\mathrm{S} 16$ & - & $\checkmark$ & - & - & - & - & - \\
\hline S17 & - & $\checkmark$ & $\checkmark$ & $\checkmark$ & $\checkmark$ & - & - \\
\hline $\mathrm{S} 18$ & $\checkmark$ & - & - & - & - & - & - \\
\hline S19 & & - & $\checkmark$ & - & - & - & - \\
\hline $\mathrm{S} 20$ & $\checkmark$ & - & - & - & - & - & - \\
\hline $\mathrm{S} 21$ & - & $\checkmark$ & - & - & - & - & - \\
\hline $\mathrm{S} 22$ & - & $\checkmark$ & $\checkmark$ & $\checkmark$ & $\checkmark$ & $\checkmark$ & $\checkmark$ \\
\hline
\end{tabular}




\subsection{Unrealistic Solutions}

According to the Table 2, the theme of unrealistic answer was observed in 18 solutions. The solutions in this theme are divided into two sub-codes: The first one suggests that "Enes should buy the cardboard from the stationery next to the Vase since he would get a 3 liras profit." The clinical interviews showed that 5 student solutions (S2, S7, S11, S18, S20) gathered under this code. The following is the clinical interview performed with Student 7 on this code:

$\boldsymbol{R}:$ Could you read the question first?

S7: Shall I read it out?

R: Read it the way in which you can understand it better.

S7: Okay. (Student reads it out once) It's done.

$\boldsymbol{R}:$ Could you explain the question?

S7: There is a kid called Enes and he forgot buying the cardboards. The cardboard is 6 liras at the canteen, 3 liras there at the Vase. It asks us to help Enes.

$\boldsymbol{R}$ : Let's help, then. What would you recommend Enes to do?

S7: I think he should go and buy it from the stationery next to the Vase because he would get a 3 liras profit.

$\boldsymbol{R}$ : How did you get that he would get a profit?

S7: Because it is 6 liras at the canteen, 3 liras at the Vase;

if we subtracted 3 from 6 , we find he would get a 3 liras profit.

$\boldsymbol{R}:$ Do you think it is worth going to the Vase for 3 liras?

S7: Yes. Because Enes would save more money.

$\boldsymbol{R}:$ Do you think the problem is logical, is there anything in the problem that does not sound plausible?

S7: No, there isn't.

$\boldsymbol{R}:$ Then, the question is clear?

S7: Yes.

R: Is it difficult?

S7: It is very easy.

When examining the interview above, it is seen that the student could not make the right sense of the problem situation which he/she tried to solve on the basis of the real-life situation. He/she did not perceive the clear statement "The teacher of the technology design class asked him and his friends last week to bring cardboards in four different colors for today's class: orange, yellow, green, and pink" in the text and made a simple literal comprehension error and made an inferential comprehension error because he/she did not understand Enes' round trip to the Vase. The inferential comprehension here caused the question to be perceived by the student as a routine problem. Blum [12], Blum and Borromeo Ferri [14] stated that the mental representation of the real-life model and the problem situation is performed simultaneously in this type of problem and the mathematical model is directly constructed since routine problems can be solve without the need for real life knowledge. In this context, the student set forth the "6 Turkish liras - 3 Turkish liras" equation and turned the verbal statement into mathematical symbols, concluding the mathematical result of "he would get a 3 liras profit" by doing the mathematical operations based on that equation. Interpreting this mathematical result, the student recommended Enes to buy the cardboard from the stationery next to the Vase because Enes would save more money and achieved the real result via a wrong solution. The student was asked the question "Do you think the problem is logical, is there anything in the problem that does not sound plausible?" for validation but stated that the question was very easy and there was no confusion when solving it. This case enabled to see that the student did not perform critical reading in the stage of comprehending the problem.

The second code of the unrealistic answer theme suggests that "Enes should buy the cardboard from the stationery next to the Vase since he would get a 12 liras profit." The clinical interviews showed that 13 student solutions (S1, S3, S5, S6, $\mathrm{S} 8, \mathrm{~S} 10, \mathrm{~S} 13, \mathrm{~S} 14, \mathrm{~S} 15, \mathrm{~S} 16, \mathrm{~S} 17, \mathrm{~S} 21, \mathrm{~S} 22)$ gathered under this code. The following is the clinical interview performed with Student 21 on this code:

$\boldsymbol{R}$ : Could you read the question first?

S21: Okay. (The student read it once, highlighted the numbers) I read it.

$\boldsymbol{R}:$ Could you explain the question?

S21: The cardboard is 6 liras at the canteen, 3 liras from the stationery next to the Vase. Enes needs to buy cardboards in 4 different colors. It asks where he should buy them to get more profit.

$\boldsymbol{R}:$ Do you think it is the exact question?

S21: No, but it asks that.

$\boldsymbol{R}$ : Let's solve it, then.

S21: If he bought from the canteen, he'd pay 24 liras.

R: Why?

S21: Because he'd buy 4 cardboards at 6 liras a piece. If he bought them from the stationery next to the Vase, he'd pay 12 liras.

R: Yes.

S21: Then, we subtract 12 from 24 to find 12 liras.

$\boldsymbol{R}:$ What does 12 liras mean here?

S21: It shows that Enes would get a 12 liras profit if he bought them there at the Vase.

R: Do you think Enes should buy the cardboards from the stationery next to the Vase?

S21: He'd get a $50 \%$ profit.

$\boldsymbol{R}$ : Do you think the problem is logical, is there anything in the problem that does not sound plausible?

S21: No, there isn't.

$\boldsymbol{R}:$ Then, the question is clear?

S21: Yes.

R: Is it difficult?

S21: It is easy.

According to the interview above, the only difference between the first and second codes is that the basic comprehension observed in the first code was eliminated and the statement "The teacher of the technology design class asked him and his friends last week to bring cardboards in four different colors for today's class: orange, yellow, green, and pink" was taken into consideration. Yet, the question 
turned into a routine problem because there was no interferential comprehension as in the first code and the mathematical result of "he would get a 12 liras profit" was achieved with mathematical equations. As a result of interpreting the mathematical result, the students recommended that the cardboards should be bought from the stationery at the Vase because it would spare more money for Enes and they came to the stage of real results in the modeling cycle. The students who provided this solution could not notice that their solution was unrealistic because they thought that the conditions of buying the cardboard from the stationery next to the Vase and the school were the same. The students were asked the question "Do you think the problem is logical, is there anything in the problem that does not sound plausible?" to ensure the awareness and 8 students (S1, S5, S6, S8, S13, S15, S16, S21) completed their solutions, stating that there was no confusion about the situation and the problem was loud and clear. This case enabled to see that the student could not read the problem critically in the stage of comprehending the problem.

\subsection{Realistic Solutions}

Despite having completed their solutions, 5 (S3, S10, S14, S17, S22) of the student who achieved the result "he would get a 12 liras profit" changed their solutions on the basis of researcher's question "Do you think the problem is logical, is there anything in the problem that does not sound plausible?" and questioned how Enes would go to the stationery next to the Vase. As a result of this questioning, the students stated that Enes could go to the stationery next to the Vase by bus and would pay a carfare. Accordingly, the "Carfare" code was added to the study. The following is the clinical interview performed with Student 10 on the "Carfare" code:

$\boldsymbol{R}:$ Could you read the question first?

S10: Okay. (The student read it twice.) It's done.

$\boldsymbol{R}:$ Could you explain the question?

S10: Enes will buy 4 cardboards. A piece of carboard is 6 liras at the school, 3 liras next to the Vase; it asks us to help him decide where to buy them.

$\boldsymbol{R}:$ Do you think it is the exact question?

S10: Yes.

R: Let's solve it, then.

S10: If he bought from the canteen, he'd pay 24 liras, if he bought from stationery next to the Vase, he'd pay.

$\boldsymbol{R}:$ Is it done?

S10: No. If you subtract 12 liras from 24 liras, it'd be 12 liras.

$\boldsymbol{R}:$ What does 12 liras mean here?

S10: That he'd get a 12 liras profit if he bought it from the stationery next to the Vase.

$\boldsymbol{R}:$ What does 12 liras mean here?

S10: It shows that Enes would get a 12 liras profit if he bought them there at the Vase.

R: Do you think Enes should buy the cardboards from the stationery next to the Vase?

S10: Yes. It'd be very profitable.
$\boldsymbol{R}:$ Do you think the problem is logical, is there anything in the problem that does not sound plausible?

S10: (The student thought about it a minute and read it again) Yes, teacher.

$\boldsymbol{R}:$ What made you confused?

S10: He's supposed to go to the Vase...

R: Yes.

S10: He couldn't walk to there.

$\boldsymbol{R}:$ How would he, then?

S10: He could go by bus.

$\boldsymbol{R}:$ When did you get this issue?

S10: When I was reading it.

$\boldsymbol{R}:$ Which one?

S10: When reading for the first time.

$\boldsymbol{R}:$ Why didn't you tell, then?

S10: Because there was no carfare?

$\boldsymbol{R}$ : Does it change the result if he went there by bus?

S10: Yes. Because he'd pay for the bus. Then he might not have any money left.

R: How so?

S10: Teacher, if the carfare was 6 liras when he was going there, he'd have no many left when returning.

$\boldsymbol{R}:$ Then, what do we need to know about?

S10: The carfare.

R: Do you know about it?

S10: I don't know.

$\boldsymbol{R}:$ How can we learn about it?

S10: We can ask my elder brother, he frequently takes the bus.

R: How are we supposed to find your brother now?

S10: He's here, he's 7th-grade.

R: I know about it, too. Discounted student carfare is 1.5 liras.

S10: Then, he'd get a 9 liras profit?

R: So, where should Enes buy the cardboards from?

S10: He'd move into profit, anyways, Teacher. He should buy it from the stationery next to the Vase.

$\boldsymbol{R}:$ Is there any other point that is not plausible?

S10: Not anymore, Teacher.

According to the quoted interview above, the student did not give a realistic answer in the first place but upon the question "Do you think the problem is logical, is there anything in the problem that does not sound plausible?", it was revealed that he/she questioned how Enes would go to the stationery next to the Vase since the beginning. In this context, the student needed the extra information and restructured the problem as soon as he/she accessed the information that the carfare was 1.5 liras and concluded that Enes would have got a 9 liras profit if he had bought the cardboards from the stationery next to the Vase by doing the operation of 12-(2x1.5 liras). Next, the student recommended Enes that he should buy the cardboards from the stationery next to the Vase since he'd have 9 liras left in his pocket and this marked the real results stage. At this stage, the student was asked the question "Is there any other point that is not plausible?" but did complete the solution, saying "no" to the 
question. There were 4 other students (S4, S9, S12, S19) who questioned that Enes needs to pay for the bus but these students achieved this code on their own without the need for directing questions during the comprehension stage. The following is the clinical interview performed with Student 19 who achieved the Carfare code without getting any support in the comprehension stage:

$\boldsymbol{R}$ : Could you read the question first?

S19: Yes. (The student read it silently thrice). Teacher, I think this question is incomplete.

R: Why?

S19: Because the Vase is far away, he'd need to take a bus.

$\boldsymbol{R}:$ He could take it.

S19: But he'd pay for the bus if he took it.

$\boldsymbol{R}:$ Let's make up the missing point, then. What is it?

S19: I don't know the carfare. How much is it?

$\boldsymbol{R}:$ How can we learn about it?

S19: There are lots of busses at the corner, we could ask the drivers there.

R: I asked on behalf of you. Discounted student carfare is 1.50 liras. Can you solve the question now?

S19: If he bought the cardboards from the canteen, he'd pay 24 liras. If he bought them from the place next to the Vase, he'd pay 12 liras and 3 liras more.

R: Why would he pay 24 liras to the canteen?

S19: At 6 liras a piece, he'd buy 4 cardboards and that is 24 liras.

$\boldsymbol{R}:$ Why would he pay 12 liras to the stationery next to the Vase?

S19: Because a cardboard is 3 liras there, 4 cardboards add up to 12 liras.

R: For what would he pay 3 liras?

S19: For the bus.

R: But the carfare is 1.5 liras, why would you have him pay 3 liras?

S19: He'd pay when going there and coming back from there.

$\boldsymbol{R}$ : Keep solving it.

S19: If he bought them from the canteen, it'd be 24 liras, if he bought them from the Vase, he'd pay 15 liras including the carfare. He'd make a 9 liras profit if he bought from the Vase.

$\boldsymbol{R}:$ What would you recommend Enes to do?

S19: He would save 9 liras, I think he should buy them from the place next to the Vase.

$\boldsymbol{R}$ : Is there any other missing point you noticed in the problem?

S19: No, Teacher.

According to the quoted interview above, how the student stated that the question was incomplete while reading the problem during the transition from the real situation to the mental representation of the situation shows that he/she performed critical reading and the inferential comprehension became activated when he/she thought that Enes needed to pay for the bus. With the activation of inferential comprehension, the student structured the problem as transitioning from the mental representation of the situation to the real model and asked "how much the carfare was". The student stated that he/she could make up the lack of information about the carfare by asking the drivers about it but he/she was told that it was not necessary and the discounted student carfare was 1.50 Turkish liras. As soon as the student learned that the carfare was 1.50 Turkish liras, he/she had accessed the extra real life information necessary for the solution of the problem. In the next stage, the student mathematized the problem during the transition from the real model to the mathematical model and set forth the equation (6 lirasx4)-(4 lirasx3)+(1.50 lirasx2). To achieve the mathematical result from the mathematical model, the student worked mathematically and concluded that if Enes had bought the cardboards from the stationery next to the Vase, he would have paid 9 liras less than if he would have bought them from the canteen. The student interpreted the problem when achieving the real result from the mathematical result and thought that Enes would have spared a remarkable amount of money if he had bought the cardboards from the stationery next to the Vase, achieving the real result. Following this stage, the student was asked the question "Is there any other missing point you noticed in the problem?" for validation but did give the answer, so the interview was ended.

4 students (S3, S4, S10, S17) who achieved the Carfare code stated that it would be dangerous for Enes to go to the Vase alone upon the question "Is there any other missing point you noticed in the problem?" and the Danger code was accordingly added to the study. The following is the clinical interview performed with Student 3 on the Danger code:

S3:

R: Where would you suggest Enes to buy the cardboards from?

S3: Because he'd get a 9 liras profit, to buy them from the place next to the Vase.

$\boldsymbol{R}$ : Is there any other missing point you noticed in the problem?

S3: Yes, Teacher. Wouldn't it be dangerous for him to go the Vase alone?

R: Why?

S3: For example, my mother doesn't let me go away places alone.

R: Why?

S3: Because I'm minor. But Enes is older than me.

R: How did you get it?

S3: Because Enes is an 8th-grade.

R: How old can Enes be?

S3: I'm 10 years old. The 5th-grades are 11 years old, the 6th-grades are 12 years old, the 7th-grades are 13 years old, the 8-th grades are 14 years old. He can be 14 years old, Teacher.

$\boldsymbol{R}:$ If Enes was 14 years old, would he go to the Vase from here alone?

S3: I don't know, Teacher. 
R: I asked the 8th-grades, they all said that their mothers let them take the bus and go to the Vase alone.

S3: Then, he can go.

$\boldsymbol{R}:$ Is there any other missing point you noticed in the problem?

S3: No.

According to the quoted interview above, the student validated the answer when coming back to the real situation from the real result and stated that it would be dangerous for Enes to go the Vase on his own by looking at the problem situation from a critical point of view. When it was asked the student to evaluate this proposition, he/she first made an inferential sense of the mental representation of the situation and thought that Enes' age needed to be known so that the situation could be evaluated. During the structuring stage in the transition from the mental representation of the situation to the real model in the modeling cycle, the student needed the extra real life information and thought that he/she could access the information in his/her classroom and on the basis of his/her own age. Based on this information, achieving the mathematical model from the real model, the student stated that he was 10 years old and studying in the 4th grade and mathematized the problem by increasing the age by 1 in parallel with the grade level, concluding the mathematical result that Enes who is studying in the 8th grade could be 14 years old. Getting to the real result from the mathematical result, the student did not interpret the problem because he/she did not know whether Enes have the competence to go to the Vase on his own. In this context, the information that individuals at the age of 14 are permitted to go to the Vase alone by their parents was shared. The student interpreted that it would not be dangerous for Enes to go to the Vase alone based on this information and achieved the real result, recommending that he should buy it from the stationery next to the Vase as he would get a 9 liras profit. In this stage, 2 students (S3, S10) stated that there were no other missing points and ended the solution.

2 students (S4, S17) who achieved the Danger code and 3 students (S9, S12, S22), who could not, stated that Enes might have trouble with time if he went to the stationery next to the Vase, so the "Time" code was added to the study. The following is the clinical interview performed with Student 17 on the Time code:

S17:

R: Now that it would not be dangerous for him to go alone, do you think he should buy them from the stationery next to the Vase?

S17: It isn't dangerous but the Vase is too far away.

R: Do you think he'd get tired? He'd take the bus at the end of the day.

S17: No, Teacher, he might not make it.

$\boldsymbol{R}$ : How could we know if he made it?

S17: We need to know how many minutes it takes for the busses to go and come back.

$\boldsymbol{R}:$ How can we learn about it?
S17: Maybe it's on the internet, but we can ask the drivers. $\boldsymbol{R}:$ I asked them. How about taking a look at this table? (The information obtained from the bus drivers before was presented)

It takes 20 minutes for the busses to go to and 20 minutes to come back from the Vase if there is no traffic jam.

It takes 25 minutes for the busses to go to and 25 minutes to come back from the Vase in case of moderate traffic jam.

It takes 30 minutes for the busses to go to and 30 minutes to come back from the Vase if there is heavy traffic.

S17: (After having examined it for a while) If there was no traffic jam, it would take 20 minutes to go and 20 minutes to come back, 40 minutes in total. What if the bus didn't come by? I sometimes take the bus with my mother, it doesn't come by right away.

$\boldsymbol{R}:$ There is a bus going from the school the Vase in every 3 minutes and another one from the Vase in every 3 minutes.

S17: He'd come back in 46 minutes, then only if there was no traffic jam.

R: What if otherwise?

S17: Then, he couldn't make it.

$\boldsymbol{R}:$ How many minutes is the lunch break?

S17: An hour. If there was traffic jam, he'd go there in 30 minutes and come back in 30 minutes. And he couldn't make it if he waited for the bus.

$\boldsymbol{R}$ : What if there was moderate traffic?

S17: He could go and come back in 56 minutes. But he might lose time at the stationery, too. He might be late for the class, again.

R: What should Enes do?

S17: I think he should buy them from the school, otherwise his teacher would be angry at him.

$\boldsymbol{R}:$ Is there anything you want to add?

S17: No.

According to the quoted interview above, the student stated that Enes would get a 9 liras profit if he bought the cardboards from the stationery next to the Vase but mentioned about the time problem by thinking critically in the validation stage when coming back from the real result to the real situation. This revealed a new problem: might Enes make it to the class? The extra real life information was needed for the solution once again. This information is the round-trip duration of the bus to the Vase; the student stated that the lack of information could be remedied by looking it up on the internet or asking the bus drivers. The student was told that this was not necessary and the table which included the probabilities regarding busses round trip durations was presented. The student restructured the problem by using the new information and built the mathematical model in consideration of the traffic stats in the real model. In this context, the student achieved the mathematical results that Enes would have come back to the school in 60 minutes (lunch break) if there had been no traffic jam; he would not 
have come back in 60 minutes if there had been heavy traffic; and it would have been vague for him to come back in 60 minutes if there had been moderate traffic. The student interpreted the problem as going from the mathematical result to the real result and recommended Enes to buy the cardboards from the school because there was a risk of being late for the class and 2 students (S12, S17) ended the solution in this stage.

3 students (S4, S9, S22) who questioned the Time code revalidated their solutions and kept looking at the problem situation from a critical point of view and questioned what Enes would do if he were to buy the cardboards from the stationery next to the Vase. That is why the "Lunch" code was added to the study. The following is the clinical interview performed with Student 9 on the Danger code:

S9:

R: Do you recommend him to buy them from the school canteen because he couldn't make it?

S9: Yes, Teacher. Enes would miss the lunch if he went to the stationery next to the Vase.

$\boldsymbol{R}:$ Is lunch served at the school?

S9: Yes, Teacher.

$\boldsymbol{R}:$ At what time does it start?

S9: Starts at 12.00 am and ends at $12.30 \mathrm{pm}$.

$\boldsymbol{R}:$ He might eat lunch and then go.

S9: Then, there's no way he could make it.

$\boldsymbol{R}:$ What if he didn't eat lunch?

S9: He couldn't pay attention to the class because he was hungry.

R: Couldn't he eat somewhere else?

S9: The time isn't enough again.

$\boldsymbol{R}:$ What about the recess?

S9: Then, he'd have to pay to the canteen, too?

$\boldsymbol{R}:$ How much would he pay?

S9: He could buy a toasted sandwich at 3 liras.

$\boldsymbol{R}:$ Why a toasted sandwich?

S9: It might a sandwich, too. But there isn't anything else to eat.

$\boldsymbol{R}:$ How much is that?

S9: That's also 3 liras.

$\boldsymbol{R}:$ Then, what profit would he get if he went to the Vase?

S9: It'd drop to 6 liras.

$\boldsymbol{R}:$ Wouldn't Enes drink anything?

S9: If he did, he'd pay more and get less profit.

R: Do you think it'd be worth going to the Vase for Enes for 6 liras?

S9: If he could make it to the school, yes but he couldn't take the class if he couldn't.

R: What would you do?

S9: I'd buy them from the school canteen.

R: Why?

S9: I'd be hungry otherwise.

R: But you wouldn't be hungry. You'd eat at the canteen.

S9: My mother won't let me eat at the canteen.

R: Why?

S9: She says it's unhealthy.
R: Do you have any other plan so Enes could eat lunch at the school and make it to the class?

S9: No.

Per the interview above, the student validated the problem when coming back to the real situation from the real result and question whether Enes would make it for the lunch. The student started questioning by adding the time spent for lunch to the mathematical result obtained in the time theme. In the interpretation stage when getting to the real result from the mathematical result, the student emphasized that it was impossible for Enes to make it to the class if he ate lunch whereas it was difficult for him to make it even if he didn't eat. Upon this answer, the student was asked to evaluate the suggestion that Enes would eat at the canteen during the recess and spare his lunch break for buying the cardboards from the stationery next to the Vase. When evaluating this suggestion, the student created the mental representation of the situation by making the inferential sense and thought that Enes would pay to the canteen, too. The student needed the extra real life information in the structuring stage during the transition from the mental representation of the situation to the real model in the modeling cycle. This information is what Enes would eat and how much he would pay to the canteen. The student gave the answer on his/her own and stated that Enes had no other alternative than eating a toasted sandwich or a plain sandwich at the canteen for lunch and their price was 3 liras each. Restructuring the problem on the basis of the real-life information, the student also mathematized the problem when getting from the real model to the mathematical model and decided to exclude the lunch money from the profit which Enes would have got if he had bought the cardboards from the stationery next to the Vase. Accordingly, the mathematizing stage was completed with the equation 9-6 and the mathematical result of 6 Turkish liras was achieved. The necessary interpretation was provided by the student during the transition from the mathematical result to the real result and the student recommended Enes to buy the cardboards from the school canteen even though he would get only a 6 liras profit because he would have missed the lunch and the food at the canteen was not healthy. Student 9 gave up the solution at this point.

2 students (S4, S22) who questioned the Lunch code revalidated their answers, kept looking at the problem situation from a critical point of view and questioned the possibility that Enes might make it to the class if he ate lunch at school and bought the cardboards from the stationery next to the Vase and thought that it was possible if he went there by taking a taxi. The Taxi theme was accordingly added to the context. The following is the clinical interview performed with Student 4 on the Taxi theme:

$\boldsymbol{R}$ : Do you have any other plan so Enes could eat lunch at the school and make it to the class?

S4: If he took a taxi, he'd both eat lunch and buy the cardboards from the Vase. 
R: Why?

S4: Taxi is fast, Teacher.

R: Let's say he should take a taxi? Where would he find one?

S4: He could find its phone number on the internet.

R: Okay, let him call a taxi?

S4: Then, we must know how much he'd pay for the taxi.

$\boldsymbol{R}:$ How do we learn about that?

S4: We could ask when we call?

$\boldsymbol{R}:$ It is 25 liras to the Vase and another 25 liras from there via taxi.

S4: He'd lose much money.

R: Why?

S4: 25 liras to go, 25TL to come back, the carboards are 12 liras. He'd pay 62 liras in total. He'd buy them from the canteen at 20 liras.

R: How much would he lose?

S4:42 Turkish liras.

$\boldsymbol{R}:$ Is it a bad idea to take a taxi?

S4: Evet.

R: What should Enes do?

S4: He should buy them from the canteen, otherwise he'd miss both the class and the lunch.

According to the quoted interview above, Student 4 validated the answer when coming back to the real situation from the real result and stated that Enes would eat lunch at school, buy the cardboards from the stationery next to the Vase and could make it to the class if he took a taxi. When the student was asked to evaluate this proposition, he/she created the mental representation of the situation by making the inferential sense and thought that Enes would pay for the taxi, too. The student needed the extra real life information in the structuring stage during the transition from the mental representation of the situation to the real model in the modeling cycle. This information is how much Enes would pay for the taxi to go to the Vase. The information that it is 25 liras to go to the Vase and 25 liras to come back to the Vase by taxi was provided. Restructuring the problem based on the real-life information, the student mathematized the problem when getting to the mathematical model from the real model and determined how much Enes would pay for a taxi to go to the Vase with the equation $25+25+12$ and achieved the discrepancy between buying the cardboards from the canteen and buying them from the stationery next to the Vase with the equation $25+25+12-20$. Based on the equation obtained, the student worked mathematically and achieved the result that Enes would loss 42 liras by taking a taxi to buy cardboards. The student made the necessary interpretation getting to the real result from the mathematical result and recommended Enes to buy the cardboards from the canteen, otherwise he'd lose 42 liras.

\section{Discussion, Conclusion and Recommendations}

It was aimed in this study to evaluate primary 4th-grade students' processes of solving the shopping problem within the scope of the modeling cycle developed by Borromeo Ferri (2006). In the research, it was found that the answers obtained were divided into two themes as unrealistic solutions and realistic solutions and majority of the students could not provide a realistic solution. These findings coincide with the findings obtained in the original form of the problem which was prepared for high school students (Blum and Leiß, [11]; Blum and Borromeo Ferri, [14]. PISA (2015) results also reveal that students have trouble with solving the problem texts that include modeling around the world. In the studies conducted by Verschaffel et al. [81], Verschaffel et al. [80], and Xin et al.[87], it was found that majority of the primary school students achieved right mathematical results but could not interpret the results under real life circumstances. This reveals the fact that the relationship between mathematics and real life needs to be improved as of early ages (English, [31]; Şahin, [68]; Şahin and Eraslan, [69]. Şahin [68], Şahin and Eraslan [69] concluded in their studies with primary students that students could achieve realistic results, set accurate models and test those models when activities are performed to provide them with this skill in in-class activities.

According to another finding of the study, the students who could not provide a realistic solution preferred the short-cut approach (key words, cues) mentioned by Hegarty et al. [35]. The studies performed by Viennot and Moreau [82] and Soylu and Soylu [73] showed that number- and word-oriented solutions that are lack of deep examination of the problem solution affect student achievement in a negative way. In addition, it was observed that the students who could not provide a realistic solution solved the problem with their mathematical procedural knowledge, those who could provide a realistic solution solved the problem with their conceptual knowledge; this finding is in parallel with the findings obtained in the studies conducted by Anderson[3], Brynes \& Wasik [20], Baroody et al. [8], Boaler [15], English\& Watters [32], and Mousoulides [57]. The students who provided a realistic solution preferred the meaningful (situation-based) approach mentioned by Hegarty et al. [35] It was observed that those students were able to scrutinize the problem situation under real life circumstances, identify the consistencies and inconsistencies of the result they achieved, set new problems to eliminate the inconsistencies they identified, know how to access the extra information necessary for the solution of the problem they set and turn the problem into mathematical symbols properly. These findings obtained in the research coincide with the findings of the studies conducted by Şahin \& Eraslan [69], Blum \& Leiß [11], Blum and Borromeo Ferri [14], Schapp et al. [70], Wischgoll et al. [88], and Wijaya et al. [89]. 
It has been stated that the understanding step, which is the first step of modeling cycle, may become one of the biggest obstacles in front of the solution if it is not properly structured (Wijaya et al., [89], This situation was observed in this study, too, and it was revealed that the students who provided an unrealistic solution could not understand the problem properly. Jonassen [41] stated that modern approaches put a strong emphasize on conceptual understanding, Kintsch [46] argued that in conceptual understanding phase individual needs to comprehend the problem text literally, inferentially and critically. According to Kintsch [46] literal comprehension lets us find answers for WH-questions (e.g. who, what, where, when, how) in the text. In the study conducted by Ulu [86], it was seen that reading rate, accuracy reading percentage and prosodic reading skill have an impact on literal comprehension skill. It was concluded in the study that some of the students made the literal comprehension error. It was expected from the students to make inferential and evaluative sense beyond the literal comprehension in the problem; however, it is known that students who cannot comprehend the problem literally cannot comprehend it inferentially and evaluatively, either (Allen, [1]; Kinsch, [46]; Suk, [76]; Vacca, et al.[77]; Ulu, [86]. Similar results were achieved in this study and the literal comprehension error brought about the wrong mathematical modeling. It was determined that the students who made this error could not make sense in depth and approach the problem text from a critical point of view because they could not apprehend the relationship among the problem elements (person, event, place, time.)

Students need to reveal the implicit actions within the text so that the problem used in the research could be solved realistically. Perfetti et al. [65] state that inferential comprehension must first take place for implicit actions to be revealed. Kintsch [46] stated that inferential sense making during reading draw individuals in the problem situation, help their preliminary knowledge to kick in and contribute to the production of solutions associated with real life. The fact that majority of the students could not reveal the implicit actions in the shopping problem indicates that they could not associate the problem situation with their real-life experiences, in other words, they found it difficult to make an inferential sense. Kispal [47], Chikalanga [23], Zwiers [92], Pressley [66], and Kintsch [46] concluded that individuals reason when making inferential sense whereas Barbey and Barsalou [7], Çelik and Özdemir [25] Çetin and Ertekin [24], Umay [84] and Yurt \& Sünbül [91] found that reasoning has an impact on the problem-solving skill. As a result of the study, the fact that majority of the students could not achieve the realistic results because they could not make an inferential sense shows that they had difficulty in reasoning. Kintsch [46] stated that individuals also set a situational model during inferential sense making and there is no difference between understanding a story and understanding a problem text while Staub and Reusser [74] suggested that comprehension strategies need to be set to work. In the studies conducted by Hite [36] and Ulu et al. [86], it was seen that problem-solving achievement could be increased and errors could be mitigated by providing the comprehension strategies alone. Multitude of the problems due to inferential sense making in the study indicates that those strategies could be utilized during the understanding phase of the modeling. It was observed in the study that the most important characteristic distinguishing the students who provided a realistic solution from those who could not was that they did not perceive the event in the problem as being one way but a chain of events like in a story and revealed the causations among these events.

It is stated that implicit actions within the text need to be revealed for inferential sense making; the prerequisite for revealing those implicit actions is critical reading (Basaraba et al., [9]; Odabaş et al, [59]. It has been seen that individuals can identify the inconsistencies among the events in the text and assume a judging approach during reading (Odabaş et al., [59] and individuals who cannot read critically accept what is narrated in the text as being inarguably true and are not able to identify the implicit actions in the meaning (Aşılıoğlu, [4]. It was observed in the study that the students who provided a realistic solution approached the problem text in a questioning way and were able to see the inconsistencies within the text; those who could not provide a realistic solution accepted what is given in the problem text as being inarguably true and did direct mathematical modeling. This finding shows that the students who could not provide a realistic solution had poor reading skills. It was seen in the studies conducted by Pape [62], Viennot and Moreau [82] that identifying the inconsistencies within the problem text made a high-level contribution to the differentiation between students with high and low problem solving achievement, and these findings coincide with the results of this study. The studies conducted by Basaraba et al. [9] and Odabaş et al [59] revealed that individuals who have critical reading skill perform the act of reading by asking themselves questions, therefore keeping their minds vivid all the time. The fact that some of the students who provided a realistic solution stated the missing points they saw in the problem during the understanding phase and constantly questioned their own solutions shows that they acquired this skill. There were students who could not provide a realistic solution at the beginning but expressed the points which confused them and provided the realistic solution upon researcher's question "Do you think the problem is logical, is there anything in the problem that does not sound plausible?" This finding obtained in the study is in parallel with the finding obtained in the studies of Boaler [15], English\& Watters [32], Mousoulides, [57] and Wischgoll et al [88] that students could notice their mistakes and correct their answers and be encouraged for expressing themselves when clinical interviews were supported with directing questions. The students who could not provide a realistic solution was asked the question "Do you think the problem is logical, is there anything in the problem that does not sound plausible?", but 
all of them gave the answer no. This finding indicates that the students who could not provide a realistic solution could not read the problem critically.

In the next phase of the modeling cycle, individuals collect information on the implicit actions they revealed during the phase of understanding the problem and set forth new problems. Blum and Borromeo Ferri [14] stated that this phase is called "structuring" and directly influenced by the understanding phase. During the understanding phase, what is expected from individuals who question "how Enes would go to the Vase, whether it would be dangerous for him to go to the Vase alone, he would have enough time if he went to the Vase, and what he would do about lunch if he went to the Vase" is to collect data for the solution of these problems. It was concluded in the study that the students who provided a realistic solution knew how to access the information necessary for the solution of these problems, could set forth right problems by using this information and achieve the mathematical results by mathematizing the problems they set forth properly. It was observed that the students who could not provide a realistic solution achieved the mathematical solution by sticking to the data in the problem text only without structuring the problem because they could not reveal the implicit actions within the problem. These findings obtained in the study coincide with the findings obtained in the studies which have been conducted by Blum and Leiß, [11], Blum and Borromeo Ferri [14], English [31], Şahin [68], and Şahin and Eraslan [69].

According Blum and Borromeo Ferri [14], another important element that makes modeling problems superior to word problems is the interpreting phase because modeling problems are interpreted in consideration of many conditions while word problems are interpreted on the basis of a single condition. It was observed in the study that the students who could not provide a realistic solution focused only on what profit Enes would get and the students who provided a realistic solution took other factors such as time, lunch, danger as well as profitability when advising Enes. This finding enabled us to see that the students providing a realistic solution look at the problem situation multidimensionally. It is expected from the individuals to validate the answer after the interpreting phase. According to Blum and Borromeo Ferri [14], the validation process aims at evaluating the results achieved under real life circumstances, identifying any inconsistencies between the result and the real life and eliminating them by setting forth new problems, making the model become more realistic. It was observed in the study that the students providing a realistic solution made their solutions become more realistic by constantly giving cyclical reactions based on the validation phase; however, the students who could not provide a realistic solution did not perform validation. This finding of the research is in parallel with the findings obtained in the studies of Maass [52], Wijaya et al.[89], and Eraslan and Kant [33].

Some recommendations were developed in accordance with the research results. It was seen in the study that most of the primary school 4th-grade students found it difficult to reveal implicit actions within the text in the problem solutions requiring mathematical modeling. The studies which were successful in the modeling activities were found to have high levels of sense making and critical reading skill. In this context, efforts can be made to improve inferential comprehension and critical reading skills in in-class modeling activities. It was also observed in the study that the students who provided a realistic solution validated their answers to determine the consistency of the problem whereas those who could not provide a realistic solution focused on the mathematical result. In this context, studies should be performed to improve students' validating skills in in-class activities. While they were small in numbers, it was seen that the primary school students could model and test that model, but the teacher of the application classroom had not been including the modeling problems in the class. Accordingly, another study can be performed to determine teacher opinions on the modeling problems which provide students with realistic mathematizing skill, and teachers can be trained on the subject.

\section{REFERENCES}

[1] Allen, J. (1985). Inferential comprehension: The effects of text source, decoding ability, and mode, Reading Research Quarterly 20: 603-615

[2] Altun, M. (2005). Ortaöğretimde Matematik Öğretimi. Bursa: Aktüel Alfa Bas. Yay.

[3] Andersson, U. (2010). Skill Development in Different Components of Arithmetic and Basic Cognitive Functions: Findings from a 3-Year Longitudinal Study of Children with Different Types of Learning Difficulties. Journal of Educational Psychology. Vol. 102, No. 1, 115-134

[4] Aşilioğlu, B. (2008). Bilişsel öğrenmeler için eleştirel okumanın önemi ve onu geliştirme yolları. Dicle University Journal of Ziya Gokalp Education Faculty, 11.

[5] Baki, A., Güven, B., \& Karataş, İ. (2002). Dinamik geometri yazılımı cabri ile keşfederek öğrenme. V. Ulusal Fen Bilimleri ve Matematik Eğitimi Kongresi'nde sunulan bildiri, Orta Doğu Teknik Üniversitesi, Ankara.

[6] Baki, A., Kartal, T. (2004). Kavramsal ve İşlemsel Bilgi Bağlamında Lise Öğrencilerinin Cebir Bilgilerinin Değerlendirilmesi, 2 (1).

[7] Barbey, A. K., \& Barsalou, L. W. (2009). Reasoning and problem solving: Models. In L. Squire (Ed.), Encyclopedia of neuroscience (pp. 35-43). Oxford: Academic Press.

[8] Baroody, A. J., Feil, Y., \& Johnson, A. R. (2007). An alternative reconceptualization of procedural and conceptual knowledge. Journal for Research in Mathematics Education, $38,115-131$.

[9] Basaraba, D., Yovanoff, P., Alonzo, J., \& Tindal, G. (2013). 
Examining the structure of reading comprehension: do literal, inferential, and evaluative comprehension truly exist?. Reading and Writing, 26(3), 349-379.

[10] Blum ,W. (2015) Quality Teaching of Mathematical Modelling: What Do We Know, What Can We Do? S.J. Cho (ed.), The Proceedings of the 12th International Congress on Mathematical Education, DOI 10.1007/978-3-319-12688-3 9

[11] Blum, W., \& Leiss, D. (2005). „Filling Up “-the problem of independence-preserving teacher interventions in lessons with demanding modelling tasks. In CERME 4-Proceedings of the Fourth Congress of the European Society for Research in Mathematics Education (pp. 1623-1633).

[12] Blum, W. \& Leiß, D. (2006). "Filling up"- The problem of independence-preserving teacher interventions in lessons with demanding modelling tasks. In: Bosch, M. (Ed.), CERME-4-Proceedings of the Fourth Conference of the European Society for Research in MathematicsEducation. Guixol.

[13] Blum, W. \& Niss, M. (1991). Applied mathematical problem solving, modelling, applications, and links to other subjects state, trends and issues in mathematics instruction. In: Educational Studies in Mathematics 22(1), 37-68.

[14] Blum, W., \& Ferri, R. B. (2009). Mathematical modelling: Can it be taught and learnt?. Journal of mathematical modelling and application, 1(1), 45-58.

[15] Boaler, J. (2001) Mathematical modelling and new theories of learning. Teaching Mathematics and its Applications, 20(3), $121-128$

[16] Borromeo Ferri, R. (2006). Theoretical and empirical differentiations of phases in the modelling process. ZDM, 38(2), 86-95.

[17] Borromeo Ferri, R. (2007). Modelling problems from a cognitive perspective. In: Haines, C. et al. (Eds), Mathematical Modelling: Education, Engineering and Economics. Chichester: Horwood, 260-270.

[18] Borromeo Ferri, R. \& Blum, W. (2009). Insight into Teachers' Unconscious Behaviour in Modeling Contexts. In: Lesh, R. et al. (Eds), Modeling Students' Mathematical Modeling Competencies. New York: Springer, 423-432.

[19] Borromeo Ferri, R. \& Blum, W. (2010). Mathematical Modelling in Teacher Education -Experiences from a Modelling Seminar. In: Durand-Guerrier, V., Soury-Lavergne, S. \& Arzarello, F.(Eds),CERME-6- ProceedingsoftheSixthC ongressoftheEuropeanSocietyfor Research in Mathematics Education. INRP, Lyon 2010, 2046-2055.

[20] Byrnes, J. P., \& Wasik, B. A. (1991). Role of conceptual knowledge in mathematical procedural learning. Developmental Psychology, 27, 777-786

[21] Chamberlin, M. T. (2004). Design principles for teacher investigations of student work. Mathematics Teacher Education and Development, 6, 61-72.

[22] Charles, R.I., Lester, F.K. (1984). “An evaluation of a process-oriented instructional program in mathematical problem solving in grades 5 and 7". Journal for Research in Mathematics Education, S. 15, ss. 15-34

[23] Chikalanga, I. (1992). A Suggested Taxonomy of Inferences for Reading Teacher, Reading in a Foreign Language, 8 (2), 697-709

[24] Çelik, D., Güler, M. (2013) İlköğretim 6. Sınıf Öğrencilerinin Gerçek Yaşam Problemlerini Çözme Becerilerinin İncelenmesi. Dicle Üniversitesi Ziya Gökalp Eğitim Fakültesi Dergisi, 20 180-195

[25] Çelik, A. ve Özdemir, E. Y. (2011). İlköğretim öğrencilerinin orantısal akıl yürütme becerileri ile oran-orantı problemi kurma becerileri arasındaki ilişki. Pamukkale Üniversitesi Eğitim Fakültesi Dergisi, 30(1), 1-11.

[26] Çetin, H., \& Ertekin, E. (2011). The relationship between eighth grade primary school students' proportional reasoning skills and success in solving equations. International Journal of Instruction, 4(1), 47-62.

[27] Cummins, D. D., Kintsch, W., Reusser, K., \& Weimer, R. (1988). The role of understanding in solving word problems. Cognitive Psychology, 20, 405-438.

[28] Elo, S., \& Kyngäs, H. (2008). The qualitative content analysis process. Journal of Advanced Nursing 62(1), 107-115.doi: 10.1111/j.1365-2648.2007.04569.x

[29] English, L. D. (2003). Mathematical modelling with young learners. S. J. Lamon, W. A. Parker ve S. K. Houston (Ed.). Mathematical modelling: A way of life içinde (s. 3-18). Chichester, UK: Horwood Publishing.

[30] English, L. D., \& Watters, J. J. (2005). Mathematical modeling in third-grade classrooms. Mathematics Education Research Journal, 16, 59-80.

[31] English, L. D. (2011). Complex modelling in the primary/middle school years. G. Stillman ve J. Brown (Ed.), ICTMA Book of Abstracts (s. 1-10). Melbourne, Victoria: Australian Catholic University.

[32] English, L. D., \& Watters, J. (2004). Mathematical modeling in the early school years. Mathematics Education Research Journal, 16(3), 59-80.

[33] Eraslan, A. ve Kant, S. (2015). Modeling processes of 4th-year middle-school students and the difficulties encountered. Educational Sciences: Theory ve Practice, 15(3), 809-824.

[34] Frederiksen, N., Glaser, R., Lesgold, A., \& Shafto, M. (Eds.) (1990). Diagnostic monitoring of skill and knowledge acquisition. Mahwah, NJ: Lawrence Erlbaum.

[35] Hegarty, M., Mayer, R. E., \& Monk, C. A. (1995). Comprehension of arithmetic word problems: A comparison of successful and unsuccessful problem solvers. Journal of Educational Psychology, 87, 18-32.

[36] Hite, S. (2009). Improving Problem Solving by Improving Reading Skills. Math in the Middle Institute Partnership Summative Projects for MA Degree. University of Nebraska - Lincoln

[37] Hidiroğlu, Ç. N., Dede, A. T., Semiha, K. U. L. A., \& Güzel, E. B. (2014). Matematiksel modelleme süreci çerçevesinde ögrencilerin kuyruklu yildiz problemine ilişskin çözümleri. Mehmet Akif Ersoy Üniversitesi Ĕ̈itim Fakültesi Dergisi, 1(31), 1-17.

[38] Hsieh, H., \& Shannon, S.E. (2005). Three approaches to qualitative content analysis. Qualitative Health Research, 15, 1277-1288. doi: 10.1177/1049732305276687. 
[39] Hunting, R. P. (1997). Clinical interview methods in mathematics education research and practice. Journal of Mathematical Behavior, 16(2), 145-165.

[40] Jitendra, A. K., \& Hoff, K. (1996). The effects of schema-based instruction on the mathematical word problem solving performance of students with learning disabilities. Journal of Learning Disabilities, 29, 422- 432.

[41] Jonassen, D. H. (2003). Using cognitive tools to represent problems. Journal of Research on Technology in Education, 35(3), 362-381

[42] Karataş, İ. \& Güven, B. (2004). 8. Sınıf öğrencilerinin problem çözme becerilerinin belirlenmesi: Bir özel durum çalışması. Milli Eğitim Dergisi, 163, 132-143.

[43] Keene, E. O. ve Zimmermann, S. (1997). Mosaic of thought: Teaching comprehension in a reader's workshop. Portsmouth, NH: Heinemann.

[44] Kieren, T. (1993). Rational and fractional numbers: From quotient fields to recursive understanding. In T. Romberg (Ed.), Rational numbers: An integration of research (pp.4984). Hillsdale, NY: Erlbaum.

[45] Kintsch, W., \& Greeno, J. G. (1985). Understanding and solving word arithmetic problems. Psychological Review, 92 (1), 109-129

[46] Kintsch, W. (1988). The role of knowledge in discourse comprehension: A construction integration model. Psychological Review, 95, 163-182.

[47] Kispal, A. (2008). Effective Teaching of Inference Skills for Reading. Literature Review. Research Report, DCSF-RR031, 2008. ED501868

[48] Leighton, J. P., \& Sternberg, R. J. (2003). Reasoning and problem solving. In A. F. Healy \& R. W. Proctor (Eds.), Experimental Psychology (pp. 623-648). Volume 4 in I. B. Weiner (Editor-in-Chief) Handbook of psychology. New York: Wiley.

[49] Lapp, D., \& Flood, J. (1983). Teaching reading to every child. New York: MacMillan

[50] Lesh, R.A. \& Doerr, H.M. (2003). Beyond constructivism: A models and modelling perspective on teaching, learning, and problem solving in mathematics education. Mahwah: Lawrence Erlbaum.

[51] Maass, K. (2010). Classification scheme for modelling tasks. Journal für Mathematik-Didaktik, 31(2), 285-311.

[52] Maass, K. (2007). Modelling tasks for low achieving students. First results of an empirical study. In D. Pitta-Pantazi \& G. Philippou (Eds.), CERME 5 - Proceedings of the Fifth Congress of the European Society for Research in Mathematics Education (pp. 2120-2129). Larnaca: University of Cyprus.

[53] McCormick, S. (1992). Disabled readers' erroneous responses to inferential comprehension questions: Description and analyses. Reading Research Quarterly, 27(1), 54-77.

[54] MEB (2005). İlköğretim 1-5. Sınıflar Matematik Dersi Öğretim Programı. Ankara: Talim ve Terbiye Kurulu Başkanlığı.
[55] Merriam, S. (2009).Qualitative research: A guide to design and implementation. San Francisco, CA: Jossey-Bass. Merriam, S.B. (1998). Qualitative research and case study applications in education. San Francisco: Jossey-Bass.

[56] Merriam, S.B. (1998). Qualitative research and case study applications in education. San Francisco: Jossey-Bass.

[57] Mousoulides, N. (2007). A modeling perspective in the teaching and learning of mathematical problem solving (Doctoral dissertation, University of Cyprus, Cyprus). Retrieved from http://lekythos.library.ucy.ac.cy/handle/1079 $7 / 5927$

[58] Niss, M. (2003). Mathematical Competencies and the Learning of Mathematics: The Danish KOM Project. In: Gagatsis, A. \& Papastavridis, S. (Eds), 3rd Mediterranean Conference on Mathematical Education. Athens: The Hellenic Mathematical Society, 115-124.

[59] Odabaş, H., Odabaş, Y., \& Polat, C. (2008). Üniversite öğrencilerinin okuma alışkanlığı: Ankara Üniversitesi örneği. Bilgi Dünyas1, 9(2), 431-465.

[60] Özensoy, A. U. (2011). Eleștirel okumaya göre düzenlenmiş sosyal bilgiler dersinin eleştirel düşünme becerisine etkisi. Mersin Üniversitesi Eğitim Fakültesi Dergisi, 7(2).

[61] Özsoy, G. (2007). Illköğretim 5. Sinıfta Problem Çözme Becerisi ile Matematik başarısı arasındaki ilişki. Yayınlanmamıs doktora tezi. Gazi üniversitesi. Ankara.

[62] Pape, S. J. (2004). Middle school children's problem-solving behavior: A cognitive analysis from a reading comprehension perspective. Journal for Research in Mathematics Education 35 , pp. 187-219.

[63] Passolunghi, M.C., \& Pazzaglia, F. (2005). A comparison of updating processes in children good or poor in arithmetic word problem-solving. Learning and Individual Differences, $15,257-269$

[64] Passolunghi, M. C., \& Pazzaglia, F. (2004). Individual differences in memory updating in relation to arithmetic problem solving. Learning and Individual Differences, 14, 219-230.

[65] Perfetti, C. A., Landi, N., \& Oakhill, J. (2005). The acquisition of reading comprehension skill. In M. J. Snowling \& C. Hulme (Eds.), The science of reading: A handbook (pp. 227-247). Malden, MA: Blackwell.

[66] Pressley, M. (2000). What should comprehension Instruction be the Instruction of?. In: Kamil, M. L., Mosenthal, P. B., Pearson, P. D., Ban, R. (Ed.), Handbook of Reading Research, (ss.545-562), Mahwah, NJ: LEA.

[67] Reusser, K. (1985). From situation to equation. On formulation, understanding and solving "situation problems". Institute of Cognitive Science, University of Colorado at Boulder. Technical Report No. 143.

[68] Şahin, N. (2014). İlkokul 4. sinıf öğrencilerinin model oluşturma etkinlikleri üzerindeki düşünme süreçleri (Yüksek lisans tezi). Ondokuz Mayıs Üniversitesi Eğitim Bilimleri Enstitüsü, Samsun.

[69] Sahin, N., \& Eraslan, A. (2016). Modeling Processes of Primary School Students: The Crime Problem. Egitim Ve Bilim-Education and Science, 41(183), 47-67. 
[70] Schapp, S., Vos, P., \& Goedhart, M. (2011). Students overcoming blockages while building a mathematical model: Exploring a framework. In G. Kaiser, W. Blum, R. B. Ferri, \& G. Stillman (Eds.), Trends in teaching and learning of mathematical modelling: The 14. ICMTA Study (pp. 137146). New York, NY: Springer.

[71] Schwarzkopf, R. (2007). Elementary modelling in mathematics lessons: The interplay between "real-world" knowledge and "mathematical structures". In W. Blum, P. L. Galbraith, H.-W. Hillsdale, NJ: Lawrence Erlbaum Associates. Henn, \& M. Niss (Eds.), Modelling and applications in mathematics education (pp. 209-216). New York: Springer.

[72] Smith, G.G., Gerretson, H., Olkun, S. \& Joutsenlahti, J. (2010). Effect of causal stories in solving mathematical story Problems. Hacettepe Üniversitesi Eğitim Fakültesi Dergisi (H. U. Journal of Education) 39: 284-295

[73] Soylu, Y. \& Soylu, C. (2006). Matematik derslerinde başarıya giden yolda problem çözmenin rolü. İnönü Eğitim Fakültesi Dergisi, 7(11), 97-111.

[74] Staub, F.C. \& Reusser, K. (1995). The role of presentational structures in understanding and solving mathematical word problems. In C.A. Weaver, S. Mannes \& C.R. Fletcher (eds.), Discourse comprehension. Essays in honor of Walter Kintsch (pp. 285-305). Hillsdale, NJ: Lawrence Erlbaum.

[75] Steele, D.F ve Johanning, D.I. (2004). A schematic-theoretic view of problem solving and development of algebraic thinking. Educational Studies in Mathematics 57, 65-90.

[76] Suk, H.J. (1997). The effects of language ability, text presentation style and the nature of questions inference, Doktora tezi, Chong-buk University. Kore

[77] Vacca, J. A. L., Vacca, R. T., Gove, M. K., Burkey, L. C., Lenhart, L. A., \& Mckeon, C. A. (2006). Reading and learning to read. Boston: Allyn and Bacon

[78] Vaismoradi, M.,Turunen, H., \& Bondas, T. (2013). Content analysis and thematic analysis: Implications for conducting a qualitative descriptive study. Nursing \& Health Sciences.15(3), 398-405.doi: 10.1111/nhs.12048

[79] Van Dijk, T. A., \& Kintsch, W. (1983). Strategies of discourse comprehension. New York: Academic Press.

[80] Verschaffel, L., De Corte, E., \& Vierstraete, H. (1999). Upper elementary school pupils' difficulties in modeling and solving nonstandard additive word problems involving ordinal numbers. Journal for Research in Mathematics Education, $30(3), 265-285$.

[81] Verschaffel, L., Greer, B., \& De Corte, E. (2000). Making sense of word problems. Lisse, The Netherlands: Swets and Zietlinger.

[82] Viennot, D.C. ve Moreau,S.(2007). Arithmetic problems at school: When there is an apparent contradiction between the situation model and the problem model. British Journal of Educational Psychology (2007), 77, 69-80

[83] Teong .K.S. (2002). Metacognitive Intervention Strategy and Word Problem Solving in a Cognitive-Apprenticeship-Comp uter-Based Environment. National Institute of Education, Nanyang Technological University.
[84] Umay, A. (2003). Matematiksel muhakeme yeteneği. Hacettepe Üniversitesi Eğitim Fakültesi Dergisi, 24(3), 234-243.

[85] Ulu, M., Tertemiz, N., Peker, M. (2016). The Effect of Comprehension and Problem Solving Strategy Training on 5th Graders' Non-Routine Problem Solving Success. Afyon Kocatepe Üniversitesi Sosyal Bilimler Dergisi / 18 (2), 303-340

[86] Ulu, M. (2016). A Structural Equation Model to Explain the Effect of Fluent Reading, Literal Comprehension and Inferential Comprehension Levels of Elementary School 4th Grade Students on Success in Problem Solving. Egitim ve Bilim, 41(186).

[87] Xin,Z., Lin,C.,Zhang.L ve Yan, R.(2007). The Performance of Chinese Primary School Students on Realistic Arithmetic Word Problems. Educational Psychology in Practice, Vol. 23, No. 2, , pp. $145-159$

[88] Wischgoll, A.,Pauli, C., Reusser, K.(2015). Scaffolding--How Can Contingency Lead to Successful Learning When Dealing with Errors?. The International Journal on Mathematics Education, v47 n7 p1147-1159 Nov 2015.

[89] Wijaya, A., Van den Heuvel-Panhuizen, M., Doorman, M., \& Robitzsch, A. (2014). Difficulties in solving context-based PISA mathematics tasks: An analysis of students' errors. The Mathematics Enthusiast, 11(3), 555-584

[90] Yıldırım A., \& Şimşek, H. (2013).Sosyal bilimlerde nitel araştırma yöntemleri. (9. Baskı). Ankara: Seçkin Yayıncılık.

[91] Yurt, E. ve Sünbül, A. M. (2014). A Structural Equation Model Explaining the Mathematics Achievements of the 8th Grade Students, Educational Sciences: Theory \& Practice, 14(4), 1629-1653

[92] Zwiers, J. (2004). Making inferences and predictions. In: Money,M.M. (Ed.), Building Reading Comprehension Habits in Grades 6-12: a Toolkit of Classroom Activities, 2.Edt.,Chapter 5, (ss.99-122), Newark DE: International Reading Assoc.

[93] Liang, X. (2010). Assessment use, self-efficacy and mathematics achievement: Comparative analysis of PISA 2003. Data of Finland, Canada and the USA. Evaluation \& Research in Education, 23(3), 213-229.

[94] Schleicher, A. (2007). Can competencies assessed by PISA be considered the fundamental school knowledge 15-year-olds should possess? Educational Change, 8(4), 349-357.

[95] Yore, L. D., Anderson, J. O., \& Hung Chiu, M. (2010). Moving PISA results into the policy arena: Perspectives on knowledge transfer for future considerations and preparations. International Journal of Science and Mathematics Education, 8(3), 593-603.

[96] Kaur, B. (1997). Difficulties with problem solving in mathematics. The Mathematics Educator, 2(1), 93-112.

[97] Kaur, B. \& Yeap, B. H. (2009). Mathematical problem solving in Singapore schools. In B. Kaur, B. H. Yeap, \& M. Kapur (Eds.), Mathematical problem solving: Yearbook 2009 (pp. 3-13). Singapore: Association of Mathematics Education and World Scientific 
[98] OECD. (2016). PISA 2015 results: What students know and can do. Student performance in reading, mathematics, and science (Vol. I). Paris: OECD.

[99] Stillman, G. (2011). Applying Metacognitive Knowledge and Strategies in Applications and Modelling Tasks at Secondary School. In: Kaiser, G. et al. (Eds). Trends in Teaching and Learning of Mathematical Modelling (ICTMA 14). Dordrecht: Springer, 165-180.
[100] Galbraith, P. \& Stillman, G. (2006). A framework for identifying student blockages during transitions in the modelling process. In: Zentralblatt für Didaktik der Mathematik 38(2), 143-162.

[101] National Academy of Education, Committee on Teacher Education. (2005). Preparing teachers for a changing world. San Francisco, CA: Jossey-Bass. 